\title{
DAMPAK PANDEMI COVID-19 TERHADAP PEMBELAJARAN DARING MATA PELAJARAN PAI
}

\author{
Washilatun Novia dan Wasehudin* \\ Universitas Islam Negeri SMH Banten, Indonesia \\ *E-mail:wasehudin@uinbanten.ac.id
}

\begin{abstract}
This study aims to analyze the impact of the COVID-19 pandemic on the implementation of online learning of Islamic Religious Education (IRE) in elementary schools. By using the literature study method, this study found that the COVID-19 pandemic had a positive and negative impact on the implementation of online learning in elementary schools. The impact is experienced by students, parents, teachers, and has an impact on learning itself. On the positive side, online learning can prevent transmission of the virus to other people, the learning atmosphere at home for students can be more conducive, parents can increase their time together with children, teachers can improve digital literacy skills, and learning can be more varied. On the other hand, online learning has the opportunity to widen the gap between students in rural areas and students in urban areas due to differences in facilities, parents' educational background, internet access and technology.
\end{abstract}

Keywords: Online Learning, Islamic Religious Education (IRE),Covid-19 Pandemic, Elementary School

Abstrak. Penelitian ini bertujuan untuk menganalisis dampak pandemi covid-19 terbadap penyelenggaraan pembelajaran daring Pendidikan Agama Islam (PAI) di Sekolah Dasar. Dengan menggunakan metode studi kepustakaan, penelitian ini menemukan pandemi covid-19 memberikan dampak yang positif dan negatif terhadap implementasi pembelajaran daring di lingkup Sekolah Dasar. Dampak tersebut dialami oleh siswa, orang tua, guru, dan berdampak pada pembelajaran itu sendiri. Pada sisi positif, pembelajaran daring dapat mencegah penularan virus ke orang lain, suasana belajar di rumah bagi siswa dapat lebih kondusif, orang tua dapat menambah waktu kebersamaannya dengan anak, guru mampu meningkatkan kemampuan literasi digital, dan pembelajaran dapat lebih variatif. Pada sisi lain, pembelajaran daring berpeluang untuk. memperlebar kesenjangan yang terjadi antara siswa di perdesaan dengan siswa di perkotaan karena perbedaan fasilitas, latar belakang pendidikan orang tua, akses internet dan teknologi.

Kata Kunci : Pembelajaran Daring, Pendidikan Agama Islam, Pandemi Covid-19, Sekolah Dasar

TARBAWY: Indonesian Journal of Islamic Education - Vol. 8 No. 1 (2021) | 23 


\section{PENDAHULUAN}

Pada tahun 2020, Badan Kesehatan Dunia (WHO, 2020) menetapkan penyebaran virus covid-19 sebagai pandemi dunia. Virus Covid-19 merupakan suatu penyakit sejenis dengan Severe Acure Respiratory Syndrome (SARS). Akan tetapi virus ini merupakan turunan dari '2019-nCoV' yang menginfeksi saluran napas. Risiko tersebut mendorong secara global memberlakukan kebijakan physical distancing yang mengarah pada lockdown (Unicef, \& WHO, 2020). Tak terkecuali Indonesia yang kemudian memberlakukan Pembatasan Sosial Berskala Besar (PSBB). Dalam kondisi demikian, aktivitas warga harus taat protokol kesehatan dan diperbolehkan beraktivitas, namun dengan pembatasanpembatasan tertentu (Kementerian Kesehatan, 2020).

Berbagai kehidupan telah terdampak secara masif oleh karena pandemi covid19 ini. Pola hidup dan sistem yang sebagaimana dijalankan sehari-hari tidak dapat lagi diterapkan. Pandemi juga berdampak terhadap sektor sosial yang melarang aktivitas perkumpulan orangorang di satu area, sehingga mengurangi intensitas bersosialisasi secara langsung. Salah satu sektor yang paling terdampak yakni sektor pendidikan. Sejak Maret 2020, Mendikbud menerbitkan Surat Edaran Nomor 4 Tahun 2020 tentang Pelaksanaan Kebijakan Pendidikan dalam Masa Darurat Penyebaran Coronavirus Disease (Covid-19) yang mengintruksikan agar pembelajaran di sekolah dilaksanakan dari rumah melalui jarak jauh atau daring. Implikasi atas surat edaran tersebut adalah penutupan sekolah-sekolah di berbagai wilayah, dan mewajibkan pembelajaran dilakukan secara daring, dari pendidikan anak usia dini hingga jenjang pendidikan tinggi. Sebagaimana dilansir oleh Unicef, \& WHO (2020), bahwa hingga Juli 2020, terdapat 1.750 juta siswa di dunia yang terdampak akibat ditutupnya sekolah.

Pelaksanaan pendidikan dilaksanakan melalui pembelajaran yang menghadirkan siswa dan guru untuk berinteraksi dalam lingkungan pembelajaran (Firmansyah et.al, 2019). Pembelajaran dijelaskan sebagai suatu proses bagi guru untuk mencerahkan pemahaman siswa dalam memperoleh pengetahuan sehingga dapat memahami materi yang diajarkan (Mansyur, 2020). Namun, paradigma pembelajaran yang menghadirkan siswa dan guru untuk berinteraksi dalam lingkungan pembelajaran merupakan paradigma klasik yang tidak dapat lagi diterapkan di masa pandemi. Setiap entitas dalam pendidikan dituntut untuk mengoptimalisasikan kemampuannya dalam memanfaatkan teknologi, mulai dari guru, murid, orang tua, hingga pemerintah.

Implementasi model pembelajaran daring diterapkan di seluruh provinsi di Indonesia. Pada awalnya, pembelajaran daring dipakai untuk mendeskripsikan sistem pembelajaran yang berbasis pada teknologi komputer. Tujuan pembelajaran daring yakni demi menyediakan pelayanan belajar yang berkualitas via jaringan dengan karakteristik terbuka dan masif agar siswa dapat dijangkau secara luas.

Kini tugas-tugas sekolah tidak lagi diberikan secara tatap muka di ruangan kelas, melainkan dilakukan di ruang virtual melalui smartphone, demikian pula 
proses pemberian materi dan pengujiannya. Sebagai jenjang pendidikan yang primer, pembelajaran di SD memiliki peran penting untuk mengedukasi siswa, baik secara kognitif, afektif, maupun psikomotorik. Penanaman karakter juga bersifat fundamental dalam pembelajaran di SD.

Dengan adanya pandemi, siswa dan guru diharuskan berinteraksi dan bersosialisasi melalui media online yang dapat diakses dari rumah. Model pembelajaran daring atau Learning from Home merupakan bentuk pembelajaran adaptif yang membawa dampak kepada berbagai pihak, baik positif maupun negatif. Beberapa entitas yang turut dipengaruhi oleh implementasi pembelajaran daring antara lain guru, murid, orang tua, dan dampak terhadap pembelajaran itu sendiri.

Seorang guru harus mampu menciptakan rancangan dan desain yang ringan dan efektif untuk pembelajaran daring. Hal tersebut dapat dibuat dengan menyesuaikan perangkat atau media daring yang tepat dengan materi yang akan diajarkan. Oleh karenanya, untuk mencapai keberhasilan tersebut, seorang guru memerlukan sebuah metode khusus. Guru harus mampu berinovasi dalam merancang, dan meramu materi, juga menciptakan metode khusus pembelajaran daring bagi guru yang mengajar pada mata pelajaran PAI. Pentingnya suatu metode pembelajaran akan berdampak terhadap peluang dan tantangan yang perlu diidentifikasi untuk beradaptasi dalam lingkungan belajar daring.

Artikel ini disusun untuk menganalisis secara konseptual implementasi dan dampak pembelajaran daring di sekolah dasar. Hasil penyusunan studi ini diharapkan dapat dimanfaatkan oleh guru PAI, dan dapat dipergunakan sebagai referensi dalam menghadapi peluang dan tantangan pembelajaran daring.

\section{METODE PENELITIAN}

Penelitian ini memilih library research atau studi kepustakaan sebagai metodenya. Riset literatur yakni riset yang diselenggarakan dengan menghimpun data berupa jurnal hasil penelitian dalam bentuk jurnal, paper atau publikasi ilmiah. Studi merupakan telaah atau kajian yang disusun guna mengkritik subjek persoalan secara sistematis dan berbasis pada fokus tertentu guna mencari solusi atas persoalan tersebut dengan merujuk pada materi kepustakaan yang relevan. Sebagaimana dijelaskan bahwa studi kepustakaan ialah studi yang sifatnya menelaah setiap peristiwa kaitannya dengan norma, nilai, dan budaya secara teoritis (Sugiyono, 2013).

Data-data pada studi ini bersumber dari bahan pustaka atau hasil studi yang telah melalui proses observasi, penulisan, serta publikasi yang diselenggarakan peneliti berdasarkan hasil risetnya. Tulisan tersebut merupakan deskripsi, kajian, atau kritik atas suatu subjek penelitian yang tengah ditelaah. Publikasi yang dimaksud yakni hasil karya tulis ilmiah yang berkaitan dengan implementasi pembelajaran daring di sekolah dasar, baik publikasi nasional maupun internasional. 


\section{HASIL PENELITIAN DAN PEMBAHASAN}

Sebelum terjadinya wabah covid 19, proses belajar dan mengajar diselenggarakan melalui kontak langsung atau bertatap muka. Namun pandemi menggeser model pembelajaran yang demikian menjadi pembelajaran virtual. Studi yang dijalankan penulis melalui telaah beberapa artikel menemukan bahwa covid-19 memberikan dampak pada murid, guru, orang tua, pembelajaran, dan dampak psikologis yang memengaruhi pihak-pihak tersebut. Dampak ini dirasakan baik secara langsung maupun tak langsung dalam sektor pendidikan.

Guru merasakan dampak dari adanya covid-19 terhadap implementasi pembelajaran daring dalam proses pendidikan. Hamdani \& Priatna (2020) telah menyelenggarakan studi untuk mengobservasi persepsi guru SD tentang dampak pandemi terhadap aktivitas belajar mengajar. Temuan dari studi tersebut mengimplikasikan bahwa sebanyak 59,21\% guru merasa nyaman dengan pembelajaran daring. Dihasilkan temuan pula bahwa guru telah menguasai literasi digital sebesar 65,78\%, terlebih yang berkaitan dengan aktivitas belajar jarak jauh, sementara guru lainnya merasa kesulitan untuk mengajar menggunakan perangkat gawai.

Mengacu pada hasil survei yang telah dianalisis, sebesar $71,05 \%$ menunjukkan tingkat pemenuhan perangkat yang memadai untuk melangsungkan pembelajaran daring. Hal tersebut ditunjang dengan hasil koneksi internet yang cukup sebesar $72,36 \%$. Dari segi penganggaran, diketahui bahwa anggaran untuk belajar daring mengalami kenaikan sejumlah 69,73\%, sedangkan lainnya menilai bahwa anggaran tersebut adalah anggaran pengganti dari anggaran riil saat belajar secara bertatap muka. Selanjutnya aplikasi daring dirasa telah memenuhi tingkat kenyamanan sejumlah 52,63\%. Angka tersebut tidak kalah tingginya dengan indikator komitmen guru di Kabupaten Subang bahwa sejumlah 65,78\% merasakan ketagihan memanfaatkan teknologi untuk melangsungkan pembelajaran daring.

Sebuah studi dalam artikel menerangkan mengenai dampak yang dialami orang tua selama pembelajaran daring di masa pandemi (Atiqah, 2020). Mengacu pada hasil data yang dianalisis, model belajar daring bagi orang tua dirasakan mampu meningkatkan intensitas orang tua dalam membimbing dan menemani anaknya saat belajar. Pembelajaran daring juga dinyatakan dapat mengembangkan kekompakan orang tua dan anak. Selain itu, orang tua mampu memahami karakter dan perilaku anak secara lebih baik, melalui belajar di rumah. Sebanyak $68 \%$ orang tua mengaku tidak merasa kerepotan dengan pembelajaran daring yang diterapkan. Anggaran untuk membeli kuota internet juga tidak melebihi dana yang seharusnya karena kebutuhan akan kuota internet termasuk dalam keperluan sehari-hari. Diperoleh hasil bahwa belajar di rumah dan mendampingi anak tidaklah menyita waktu ataupun mengganggu kegiatan orang tua. Materi pembelajaran daring tidak menyulitkan anak dalam memahami materi yang diajarkan. Namun ditinjau dari aspek kejenuhan, setengah dari jumlah responden orang tua merasa anaknya cepat bosan dan setengahnya lagi 
menganggap tidak membosankan. Meskipun demikian 51\% dari orang tua memberikan umpan balik bahwa anak kian semangat dalam belajar apabila dilaksanakan melalui daring.

Dampak selanjutnya yakni dianalisis dari aspek dinamika pembelajaran. Pembelajaran merupakan proses yang dinamis dikarenakan berhubungan dengan unsur-unsur pendidikan yang bisa berubah setiap saat, misalnya entitas siswa, guru, sistem, media belajar, lingkungan, dan sebagainya (Mansyur, 2020). Covid19 memunculkan istilah "Sekolah dari Rumah" atau Learning from Home sehingga keterlibatan orang tua dalam proses pembelajaran semakin meningkat. Model pembelajaran juga tidak lagi formal dengan peraturanperaturan sebagaimana diberlakukan di sekolah, misalnya seragam sekolah, piket kelas, dan peraturan lainnya. Selain itu, media belajar mengalami transformasi atau peralihan bentuk dari tatap muka secara langsung dengan bantuan papan tulis dan media peraga kini berubah menjadi via aplikasi daring seperti Zoom, Google Meet, Whatsapp, Edmodo, dan berbagai aplikasi lainnya. Hal ini tidak lain juga mengubah metode belajar yang dipraktikkan oleh pengajar. Guru dituntut untuk menguasai metode yang lebih efektif, efisien, namun tetap menarik bagi para murid melalui aplikasi daring. Sistem evaluasi belajar para murid juga harus mengalami penyesuaian dengan adanya pandemi yang tidak memungkinkan ujian dilaksanakan secara langsung. Pembatalan Ujian Nasional merupakan salah satu contoh dampak covid-19 terhadap perubahan sistem evaluasi pembelajaran siswa. Indikator penilaian yang biasa digunakan sebelum adanya pandemi tak dapat lagi digunakan dan guru harus menyusun atau memeriksa kembali sistem penilaian terbaik yang bisa diterapkan kepada muridnya melalui pembelajaran daring di tengah pandemi.

Pembelajaran daring menjadi bentuk pengembangan dari kemajuan teknologi dan informasi yang awalnya hanya memanfaatkan komputer dan media belajar seperti CD-ROM. Saat ini pembelajaran daring dilakukan berbasis internet dengan jarak jauh dan menggunakan media belajar yang sumbernya dapat diakses melalui internet. Interaksi dan komunikasi dalam pembelajaran daring juga dilakukan antara guru dengan muridnya melalui berbagai bentuk komunikasi virtual seperti chat, video call, voice call, dan sebagainya. Pembelajaran yang demikian diistilahkan dengan banyak istilah misalnya pembelajaran online, pembelajaran jarak jauh, e-learning, atau digital learning. Konsep pembelajaran daring serupa dengan $e$ learning, yakni pembelajaran yang pelaksanaannya secara jarak jauh dengan ditunjang oleh jaringan internet dan melalui perangkat seperti komputer atau telepon seluler (Putria et al., 2020). Pendapat tersebut didukung oleh Fitriana (2018) bahwa pembelajaran daring merupakan metode belajar yang memungkinkan pelajar dan pendidik saling terkoneksi secara daring di dalam suatu ruang kelas virtual dan bukan ruang kelas dalam bangunan fisik.

Nahdi \& Jatisunda (2020) menerangkan bahwa fasilitas yang dapat difungsikan dalam pembelajaran daring antara lain e-mail, Google Form, Google Meet, Google Classroom, Zoom Cloud Meeting, dan 
Whatsapp Group. Siswa SD merupakan pelajar yang masih dalam tahap berkembang, sehingga dianjurkan untuk memakai aplikasi yang sederhana dan cepat untuk dipelajari. Fasilitas atau platform yang dapat dioptimalisasikan kegunaannya oleh pengajar dan pelajar di SD antara lain Whatsapp Group dan media sosial seperti Facebook, Youtube, dan Instagram. Penelitian Daheri et al. (2020) mengidentifikasi bahwa pemakaian Whatsapp Group sebagai media dalam pembelajaran daring banyak dilakukan oleh jenjang pendidikan sekolah dasar. Whatsapp Group merupakan media daring yang tidak membutuhkan kuota internet terlalu besar seperti misalnya aplikasi Zoom karena dapat memanfaatkan fitur chatting atau voice note, pengoperasiannya juga sederhana dan dapat dipahami dengan cepat. Akan tetapi, hasil dari studi tersebut mengimplikasikan bahwa media Whatsapp Group kurang efektif jika digunakan untuk mencapai standar target dan indikator belajar siswa SD. Hal ini dikarenakan guru kurang komprehensif dalam mengajar melalui Whatsapp Group, sebab penjelasan yang lebih detail misalnya melalui video atau pesan suara belum secara maksimal dipraktikkan. Selain itu, faktor lain seperti tidak tercapainya indikator psikomotorik dan afektif siswa dalam pembelajaran, sinyal yang terganggu, dan orang tua yang sibuk serta latar belakang pendidikan yang masih rendah.

Temuan tersebut berbeda dengan studi yang dilaksanakan oleh Salehudin (2020) yang mengkonklusikan bahwa adopsi media sosial ke dalam e-learning semakin menimbulkan daya tarik dalam kegiatan pendidikan modern. Media sosial memiliki elemen fitur atraktif yang disukai generasi muda dengan kombinasi elemen teknologi. Media sosial juga dinilai jelas dalam implementasinya sebagai media belajar daring. Selain itu, nilai yang dikandung media sosial adalah efisien, tepat, terbaru, sehingga mampu menstimulasi daya minat siswa dalam belajar. Whatsapp juga mempunyai nilai tinggi dalam mempresentasikan materi oleh guru, sehingga cenderung digunakan sehari-hari untuk e-learning. Akan tetapi, perlu diperhatikan bahwa media sosial dan Whatsapp hanyalah media penunjang serta merangsang kreativitas dan bukan sebagai media yang utama. Sebab Whatsapp hanya berfungsi sebagai aplikasi dalam berkomunikasi, sedangkan media sosial kerap hanya bersifat satu arah misalnya Youtube, serta tidak memiliki elemen untuk mengevaluasi hasil belajar siswa.

Pada Surat Edaran Mendikbud yang mengatur pelaksanaan pendidikan selama pandemi covid-19, diterangkan tiga poin mengenai proses belajar daring. Pertama, pembelajaran daring berguna dalam menyediakan pengalaman belajar yang beresensi, tidak menuntut siswa memenuhi standar kurikulum agar naik kelas atau lulus. Kedua, pembelajaran dapat berfokus pada keterampilan seharihari, misalnya meliputi kecakapan pendidikan menghadapi covid-19. Ketiga, variasi tugas atau kegiatan antara murid satu dengan lainnya dapat berbeda, menyesuaikan minat dan akses fasilitas dalam melangsungkan pembelajaran di rumah (Afriansyah, 2020).

Pada dasarnya, konsep belajar daring dirancang tanpa harus memberatkan siswa, guru, ataupun orang tua. Namun pada praktiknya, siswa dipaksa untuk beradaptasi dengan penggunaan teknologi 
dalam waktu yang cepat, meskipun fasilitas pembelajaran daring belum memadai (Purwanto et al., 2020). Kondisi tersebut sejalan dengan studi yang dilaksanakan oleh Dewi (2020) bahwa siswa mengalami kesusahan untuk menyesuaikan diri dengan proses belajar secara jarak jauh. Kapasitas siswa untuk menyerap materi yang diajarkan cenderung lebih lamban daripada belajar tatap muka. Selama ini siswa dibiasakan belajar secara langsung melalui kegiatan membaca buku, mendengarkan guru di kelas, menyimak bacaan secara bersama, presentasi di depan kelas, dan mengerjakan soal latihan atau ujian secara langsung. Perubahan situasi akibat pandemi memunculkan pergeseran pola perilaku dalam proses pembelajaran yang signifikan. Hal inilah yang menghalangi siswa untuk secara efektif mengikuti proses pembelajaran daring.

Kendala tersebut ditambah dengan kesenjangan dalam mengakses internet antara siswa yang berada di daerah perkotaan dengan perdesaan, dan siswa yang berasal dari keluarga berekonomi rendah dengan berekonomi tinggi. Merujuk pada data BPS (2019) terkait akses internet di kalangan pelajar, dipaparkan bahwa pemanfaatan ponsel di kalangan siswa perdesaan lebih rendah dibandingkan siswa perkotaan, yakni sebesar 64,99\% berbanding 76,60\%. Di samping itu, hanya $15,43 \%$ siswa di daerah perdesaan yang memanfaatkan komputer, dikomparasikan dengan siswa di perkotaan yang sebesar 31,37\% akses pada komputer. Demikian pula halnya dengan tingkat akses internet siswa di perkotaan yang senilai $62,51 \%$, sedangkan di perdesaan sebesar 40,53\%. Angka- angka tersebut menggambarkan tingginya kesenjangan antara kondisi pemanfaatan teknologi antara pelajar di perdesaan dengan perkotaan.

Implementasi pembelajaran daring di lapangan harus dihadapkan pada fakta bahwa tidak seluruh siswa mampu menjangkau akses komputer, ponsel, atau internet. Studi yang dijalankan oleh Alifia et al. (2020) juga mengkonklusikan bahwa Belajar dari Rumah justru membuat kesenjangan dalam sektor pendidikan semakin meluas. Siswa yang bersekolah di area perdesaan minim memiliki akses gawai dengan fitur daring, akses internet, guru yang adaptif, orang tua yang bisa meluangkan waktu lebih banyak dan mendampingi belajar daring, serta kapasitas sekolah menyediakan fasilitas belajar daring berada pada tingkat yang rendah. Berbanding terbalik dengan kondisi siswa di perkotaan yang memadai secara finansial sehingga mampu mengakses pembelajaran daring tanpa kendala yang berarti. Peran pembelajaran daring seharusnya menjadi solusi bagi siswa di tengah pandemi, dan bukan justru menjadi problema baru. Oleh karenanya, peran pemerintah dalam membangun infrastruktur, menyediakan akses gawai bagi siswa di daerah perdesaan, serta siswa yang tidak berkecukupan secara finansial sangatlah fundamental.

Dampak lain yang dirasakan siswa dalam pembelajaran daring yakni jiwa sosial anak menjadi tidak bertumbuh karena berkurangnya interaksi anak dengan lingkungan sosialnya di sekolah (Purwanto et al., 2020). Merujuk pada penelitian yang diselenggarakan Pietro et al. (2020), bahwa siswa dapat merasakan 
tekanan, stres, depresi, kecemasan, dan sebagainya selama melakukan isolasi di rumah. Psikologis anak dapat terganggu karena perubahan perilaku atau kebiasaan sehari-hari yang mendadak dalam berinteraksi. Berada di kelas membuat siswa dapat bersosialisasi, bermain, dan belajar dengan temannya sehingga menumbuhkembangkan aspek psikologis siswa. Meskipun pembelajaran daring tidak sepenuhnya menghilangkan kesempatan anak untuk bersosialisasi, namun siswa SD lebih membutuhkan pembelajaran di ruang kelas yang memungkinkannya berinteraksi tatap muka dengan temannya dibandingkan dengan pembelajaran daring.

Dampak covid-19 bagi guru terhadap implementasi pembelajaran daring di SD dikemukakan oleh Hamdani \& Priatna, (2020) bahwa guru merasakan kenyamanan dalam melangsungkan pembelajaran daring, literasi digital yang dikuasai guru telah mencukupi, perangkat yang difungsikan sudah memadai, anggaran pembelajaran daring meningkat, dan komitmen guru semakin kuat. Pernyataan tersebut didukung oleh pendapat Zhang \& Yanchun (2017) bahwa pembelajaran daring ialah model belajar yang nyaman dan bersifat terbaru dengan basis teknologi yang berdampak positif terhadap sistem pendidikan modern. Dengan demikian, pembelajaran ini perlu didukung oleh pemanfaatan media yang menunjang kegiatan e-learning, misalnya multimedia digital.

Hasil temuan yang mengemukakan dampak positif pembelajaran daring bagi guru tidak sejalan dengan studi Putria et al. (2020) yang menemukan fakta bahwa seorang guru masih memiliki banyak kendala dalam melangsungkan proses belajar daring. Guru mengungkapkan bahwa tingkat partisipasi siswa SD selama belajar daring masih belum mencapai seratus persen, bahkan terdapat sejumlah murid yang sejak awal tidak menghadiri kelas daring sama sekali. Hal ini mengakibatkan kesulitan guru dalam memberikan penilaian pada siswa. Di samping itu, guru merasa tidak nyaman karena tidak dapat secara maksimal mengajarkan materi dan lebih banyak memberikan tugas saja.

Ketidaknyamanan guru dalam melaksanakan pembelajaran daring di rumah juga dinyatakan melalui studi yang diselenggarakan oleh Rokhani (2020). Guru merasa tidak nyaman jika pekerjaan dalam mengajar diselesaikan dari rumah. Lebih lanjut, guru menyatakan bahwa bekerja dari rumah tidak mendorong produktivitas dan kreativitas dalam bekerja, dibandingkan dengan bekerja di sekolah. Hal ini dikarenakan suasana kerja yang dinilai bersifat monoton sehingga timbul rasa jenuh. Guru merasa waktunya dalam mengajar menjadi berkurang dan khawatir terhadap adanya kemungkinan prestasi siswa menjadi menurun. Ditambah dengan rendahnya pemahaman guru yang sudah senior dalam mengimplementasikan sistem belajar jarak jauh memakai aplikasi pada gawai.

Sebelum adanya pandemi, sekolah menjadi tujuan anak-anak tiap pagi hari dari rumah masing-masing. Keberadaan anak dirasa aman karena berada di lingkungan sekolah yang bisa diawasi oleh guru. Orang tua tidak merasa khawatir dengan keberadaan, pertumbuhan, atau perkembangan anak karena dianggap telah berada di tempat yang selayaknya. Sehingga selama anak berada di sekolah, orang tua dapat memanfaatkan waktu 
yang dimilikinya, untuk mengerjakan halhal lain. Beberapa orang tua memanfaatkan waktunya untuk bekerja, baik di rumah maupun luar rumah, selagi anak bersekolah. Sedangkan beberapa orang tua memutuskan untuk mengerjakan pekerjaan rumah tanpa harus mengawasi anak-anak. Namun pandemi covid-19 yang berimbas pada penutupan sementara sekolah-sekolah membuat orang tua tidak lagi dapat beraktivitas sebagaimana biasanya. Orang tua memperoleh tanggung jawab untuk mendampingi dan membimbing anak agar dapat melangsungkan pembelajaran daring dengan optimal bagi anak setiap harinya. Namun, dengan ini juga orang tua dapat lebih menghabiskan waktunya bersama anak untuk mendekatkan diri dan memahami anak secara lebih baik. Dengan demikian, covid-19 memberikan dampak kepada orang tua melalui pembelajaran daring, baik dampak positif maupun negatif.

Nilai-nilai positif dalam pembelajaran daring dijabarkan oleh Dina (2020) bahwa melalui pembelajaran daring maka orang tua bisa lebih membimbing anaknya, meningkatkan kekompakan antara orang tua dan anak, orang tua mampu memahami karakter anaknya lebih baik. Pembelajaran daring juga tidak membuat orang tua kerepotan, anggaran untuk kuota internet tidak melebihi batas wajar, dan aktivitas belajar daring tidak menyita waktu orang tua. Hasil studi tersebut tidak sejalan dengan studi yang diselenggarakan oleh Sari et al. (2021), bahwa jika ditinjau dari tingkat kesiapan ibu, konsistensi dalam sikap ibu dalam menjaga agar anak tetap di rumah saja dinilai kurang. Ibu menyadari bahwa selama new normal, ibu tetap harus membatasi aktivitas anak di luar rumah dengan senantiasa mematuhi pembatasan secara fisik dan sosial. Setiap orang tidak diperkenankan untuk beraktivitas di kerumunan. Poin tersebut telah diatur oleh UNICEF sebagai salah satu sikap untuk melindungi anak dari transmisi covid-19. Namun pada praktiknya, ibu tetap mengajak anak untuk pergi ke luar rumah, misalnya ke warung atau berbelanja di supermarket.

Selain itu, intensitas anak di dalam rumah yang relatif tinggi membuat anak bosan dan rewel. Perasaan dan energi anak tidak dapat dilepaskan dengan maksimal, sebagaimana anak biasa mencurahkannya pada temannya. Anak merasakan dorongan untuk ke luar rumah dan bermain serta bersekolah dengan sesamanya. Ibu seharusnya paham bagaimana cara mengatasi kebosanan dan kerewelan anak, namun ibu justru merasakan kebingungan untuk bermain bersama anak (Sari et al., 2021). Perasaan bingung tersebut dirasakan sebab referensi aktivitas ibu bersama anak untuk berkegiatan bersama terbatas, di samping rasa lelah dan bosan yang juga dirasakan ibu sebagai orang tua. Sebanyak 55\% ibu merasakan kebingungan dengan frekuensi kadangkadang, sering, bahkan selalu kebingungan untuk bermain dengan anak karena setiap hari hanya di rumah saja. Akibatnya, ibu menunjukkan perilaku inkonsistensi dengan mengizinkan anak bermain di luar atau sekitar rumah dengan temannya.

Ketidaksiapan orang tua juga dihasilkan dari studi oleh Lutfiah (2020) yang menjabarkan bahwa orang tua mengalami beberapa kendala selama 
mendampingi anak dalam belajar daring. Hal tersebut antara lain disebabkan oleh kurangnya ketersediaan sarana dan prasana, ketidaksiapan dalam mendampingi anak, ketidaksiapan siswa sendiri dalam melaksanakan belajar daring, serta rendahnya intensitas orang tua, guru dan siswa dalam pembelajaran. Masih banyak orang tua dan siswa yang belum mempunyai fasilitas memadai untuk melangsungkan pembelajaran daring. Terlebih orang tua yang pekerjaan sehari-harinya di luar rumah, misalnya sebagai buruh tani di sawah, atau buruh pabrik. Orang tua yang demikian tidak memiliki banyak kesempatan dan waktu luang untuk mendampingi anak belajar. Di samping itu, latar belakang pendidikan orang tua yang rendah juga memengaruhi kemampuan dalam mengakses teknologi. Akibatnya, siswa yang tidak berkomitmen untuk belajar daring akan bermalasmalasan di rumah, terlebih karena masih jenjang SD. Hal tersebut menjadi tantangan bagi orang tua untuk menerapkan kedisiplinan bagi anak selama menerapkan model belajar daring.

Lebih jauh, kondisi ini dijelaskan dalam riset yang diselenggarakan Smeru Institute (Alifia et al., 2020). Learning from Home membuat peran orang tua semakin krusial karena mereka dituntut untuk mengambil alih peran guru sebagai pendidik, sedangkan setiap orang tua memiliki kapasitas yang berbeda-beda. Latar belakang pendidikan dalam keluarga, dengan demikian, menjadi faktor penentu bagi anak terhadap pembelajarannya sehari-hari. Anak yang berada di perkotaan dengan orang tua terdidik lebih cenderung mempunyai waktu yang seimbang antara bermain dan belajar. Sebaliknya, anak yang berada di perdesaan dengan latar pendidikan orang tua yang kurang memadai lebih cenderung tidak memiliki jadwal menentu dalam belajar secara daring. Beberapa guru mengeluhkan bahwa sejumlah orang tua tidak bertindak responsif selama program Belajar dari Rumah. Hal ini disebabkan karena beberapa faktor: (a) aktivitas personal orang tua; (b) kurangnya perhatian orang tua terhadap pendidikan anak; (c) kurangnya akses orang tua pada internet dan gawai.

Komunikasi yang dibangun guru kepada siswa menjadi faktor yang esensial di tengah pembelajaran jarak jauh akibat pandemi. Merujuk pada hasil penelitian Alifia et al. (2020), dialog antara guru dan orang tua kerap mencakup diskusi tentang materi yang diajarkan, penugasan, dan perkembangan belajar anak. Orang tua berpendidikan tinggi di daerah perkotaan dan yang menyekolahkan anaknya di sekolah swasta umumnya lebih sering berkomunikasi dengan guru tentang perkembangan anak. Pola komunikasi yang demikian tidak terjadi pada orang tua berpendidikan rendah yang tinggal di perdesaan. Komunikasi yang diadakan cenderung hanya berciri satu arah, yakni menerima pelajaran dan penugasan yang diberikan kepada anak. Diperlukan upaya tegas dari para pemangku kepentingan di sektor pendidikan untuk mengatasi kesenjangan yang terjadi. Jika kondisi demikian terus dibiarkan, besar kemungkinan bahwa siswa SD yang kurang berkesempatan untuk mengakses belajar daring secara optimal akan semakin tidak menerima pendidikan yang memadai dan memperburuk kondisi pendidikan di Indonesia. 
Dampak pandemi covid-19 terhadap implementasi pembelajaran daring dapat diidentifikasi karena beberapa kendala berikut: (a) terbatasnya guru dan siswa dalam menguasai teknologi informasi; (b) kurang memadainya sarana dan prasana dalam pembelajaran daring; (c) terbatasnya akses internet yang tidak merata ke seluruh daerah; (d) ketidaksiapan dalam menyediakan anggaran yang memadai. Kendala lain yang dihadapi orang tua yakni terbatasnya referensi orang tua dalam berkegiatan bersama anak di rumah, terbatasnya waktu yang dimiliki untuk mendampingi anak karena sibuk bekerja, dan latar belakang pendidikan orang tua yang kurang dalam membantu anak melaksanakan pembelajaran daring.

Setiap kebijakan dapat menimbulkan dampak positif dan negatif tersendiri yang tidak dapat dihindari. Demikian pula halnya dengan kebijakan pemerintah mengimplementasikan pembelajaran daring di kalangan siswa usia dini hingga pendidikan tinggi. Pembelajaran daring menimbulkan kelebihan dan kekurangan yang dirasakan oleh pihak-pihak yang terlibat. Bagi siswa, manfaat yang dirasakan yakni kebebasan siswa dalam belajar menjadi semakin besar (Handayani, 2020). Siswa bebas mengakses materi pembelajaran tanpa terbatas tempat atau waktu. Waktu siswa menjadi lebih luang dalam pemanfaatannya. Siswa lebih bebas dalam bercakap-cakap karena tidak berada di situasi yang formal sebagaimana di kelas. Keuntungan lain yang diperoleh yakni siswa tidak harus mengeluarkan biaya ekstra untuk transportasi ke sekolah. Hal ini sebagaimana diungkapkan oleh
Purwanto et al. (2020) bahwa pembelajaran daring tidak membatasi waktu dan menghemat uang untuk mobilisasi ke sekolah.

Adapun kebermanfaatan lainnya yang dirasakan yakni pembelajaran daring mampu menjangkau siswa dalam jangkauan yang luas karena memanfaatkan internet, juga memudahkan siswa maupun guru dalam menyimpan materi pembelajaran. Selain itu, pembelajaran daring melatih kemandirian siswa dan meningkatkan interaktivitas, mampu mengasah memori secara lebih baik, menambah pengalaman belajar dengan beragamnya media yang dipakai antara lain audio, teks, dan video. Penyampaian materi juga dapat ditingkatkan dengan cara yang menarik, isi materi dapat diperbarui, didiskusikan, dan disimpan untuk dipelajari kembali kapan pun. Keunikan dan kemenarikan dalam belajar secara daring bagi siswa SD dapat membangkitkan motivasi belajar murid. Dengan adanya pembelajaran daring, siswa diharapkan dapat lebih aktif dalam proses pembelajarannya karena situasi yang lebih kondusif dan tenang di rumah. Siswa juga didampingi oleh orang tua sehingga dapat lebih dibimbing.

Pada sisi lain, dampak negatif juga ditimbulkan oleh pembelajaran daring. Dampak yang secara jelas dirasakan yakni kesenjangan yang terjadi antara murid di perdesaan dengan lingkungan perkotaan disebabkan akses teknologi yang kurang merata dan latar belakang pendidikan orang tua yang beragam. Kondisi demikian jika dibiarkan dapat memicu perbedaan kualitas pendidikan yang diterima antarmurid dan berdampak pada kualitas sumber daya manusia dan sistem 
pendidikan itu sendiri. Di luar dampak tersebut, murid semakin bebas mengakses internet yang mengandung informasi tak terbatas. Kebiasaan murid bergelut dengan internent memungkinkannya untuk dapat membuka situs-situs informasi yang tidak layak menurut usianya (Nahdi \& Jatisunda, 2020).

Kendati murid SD pada era milenial ini mayoritas mampu mengoperasikan gawai secara cepat, namun kemampuan anak dalam menyeleksi informasi tetap harus dimiliki. Demikian pula dengan pengawasan orang tua yang tetap harus dilakukan. Internet memudahkan akses ke sumber digital tanpa batasan terhadap konten-konten yang tidak selayaknya. Murid SD yang mempunyai rasa penasaran tinggi akan cenderung semakin aktif dalam mencari tahu sumber-sumber informasi. Hal inilah yang membuat pembelajaran daring bersifat rentan jika tanpa pendampingan orang tua. Kekurangan pembelajaran daring berdasarkan temuan studi Handayani (2020) mengidentifikasi bahwa banyaknya keluhan tentang kondisi jaringan internet yang tidak stabil. Seringnya terjadi keterlambatan, kesalahan teknis, siswa merasa kesulitan untuk fokus, dan sebagainya.

Solusi atas pembelajaran daring di tengah wabah covid-19 agar pendidikan di Indonesia tidak lagi mengalami kesenjangan merupakan tanggung jawab dan peran bersama, bukan hanya pemerintah, melainkan seluruh entitas di Indonesia. Perlu adanya sinergitas antara pemerintah, guru, orang tua, murid, dan masyarakat untuk saling membantu terselenggaranya pendidikan secara merata dan lebih baik. Langkah-langkah strategis yang dapat diambil bagi solusi atas penguatan sektor pendidikan di Indonesia selayaknya diwujudkan oleh berbagai pihak selaku pemangku kepentingan. Pemerintah berperan untuk menjaga jalannya pembelajaran daring agar tetap kondusif dan tetap sesuai dengan tujuan, yakni sebagai upaya mencerdaskan bangsa, meskipun diselenggarakan secara daring. Sebagai usaha untuk mendistribusikan akses teknologi dan informasi yang merata ke seluruh masyarakat, terutama siswa, pemerintah perlu mengadakan percepatan realisasi alokasi anggaran yang telah ditetapkan melalui Instruksi Presiden Nomor 4 Tahun 2020 tentang refocussing kegiatan, relokasi anggaran, serta pengadaan barang dan jasa dalam rangka mempercepat untuk mengatasi darurat covid-19.

Orang tua sebagai pihak yang berperan fundamental dalam mendidik anak perlu menjalankan responsibilitasnya. Ibu atau ayah yang berada di rumah perlu untuk meluangkan waktunya secara lebih banyak dalam mendampingi proses belajar anak. Sebab orang tua merupakan pelindung dan pembimbing anak sejak usia kandungan, sehingga apabila anak merasa kesulitan, anak dapat meminta bantuan orang tua. Peran orang tua dalam pembelajaran daring juga harus senantiasa menjaga komunikasi baik dengan guru. Hal tersebut dilakukan agar jika orang tua tidak dapat mengatasi persoalan anak yang berkaitan dengan penugasan atau lainnya, maka orang tua dapat menghubungi guru.

Guru juga perlu membagi porsi penugasan sesuai kemampuan tiap-tiap siswa sehingga tidak membebani siswa ataupun orang tua. Selain itu, perlunya merancang pembelajaran daring yang 
strategis, atraktif, dan esensial dengan metode-metode yang mampu membuat murid tertarik. Guru dapat memanfaatkan aplikasi yang dianjurkan pemerintah atau aplikasi sederhana seperti Whatsapp Group, media sosial seperti Youtube, Instagram, dan lainlain. Pemanfaatan media digital tersebut juga perlu dibarengi dengan penanaman literasi digital oleh guru kepada murid dan orang tua. Dengan demikian, akses terhadap konten-konten yang tidak sesuai dapat dihindari. Terlebih PAI, karena mata pelajaran ini menghendaki guru, tidak saja memberikan sederetan pengetahuan saja, aspek sikap dan keterampilan yang diwujudkan dalam bentuk akhlak mulia merupakan tujuan utamanya (Firmansyah, 2019).

Sekolah sebagai pihak yang menyelenggarakan pendidikan juga turut serta untuk bertanggung jawab dalam menyediakan fasilitas memadai untuk merespon perubahan yang terjadi di sektor pendidikan, terlebih dengan adanya pandemi covid-19. Sekolah yang responsif mampu meningkatkan minat, motivasi, dan kualitas murid yang dihasilkan bagi negeri ini. Penyediaan anggaran pembelajaran daring juga penting untuk diselenggarakan, terutama untuk memfasilitasi pihak siswa yang keluarganya tidak mampu secara finansial untuk menjangkau perangkat belajar daring. Sinergitas antara pihak siswa, orang tua, guru, sekolah, dan pemerintah merupakan kunci bagi kelancaran pembelajaran daring. Semua pihak turut berpartisipasi agar tidak melahirkan persoalan baru, melainkan solusi yang mengatasi permasalahan pendidikan di tengah pandemi covid-19.

\section{KESIMPULAN}

Pandemi covid-19 memberikan dampak yang positif dan negatif terhadap implementasi pembelajaran daring di lingkup Sekolah Dasar. Dampak tersebut dialami oleh siswa, orang tua, guru, dan berdampak pada pembelajaran itu sendiri. Pada sisi positif, pembelajaran daring dapat mencegah penularan virus ke orang lain, suasana belajar di rumah bagi siswa dapat lebih kondusif, orang tua dapat menambah waktu kebersamaannya dengan anak, guru mampu meningkatkan kemampuan literasi digital, dan pembelajaran dapat lebih variatif. Pada sisi lain, pembelajaran daring berpeluang untuk memperlebar kesenjangan yang terjadi antara siswa di perdesaan dengan siswa di perkotaan karena perbedaan fasilitas, latar belakang pendidikan orang tua, akses internet dan teknologi. Di samping itu, guru lebih mudah berkomunikasi dengan orang tua di perkotaan, sebab komunikasi yang dijalin antara guru dengan orang tua di perdesaan cenderung bersifat satu arah.

Demi menghadapi persoalan ini, perlu adanya percepatan program pemerintah untuk menanggulangi pandemi covid-19. Diperlukan sinergitas antara pihak-pihak pemangku kepentingan di sektor pendidikan SD untuk menyelenggarakan pembelajaran daring tanpa menambah persoalan baru.

\section{REFERENSI}

Afriansyah, A. (2020). Guru di Masa Pandemi: Pola Adaptasi, Komunikasi, Transformasi, dan 
Strategi Baru Mendidik Anak. MAARIF, 15(2), 394-394.

Alifia, U. E. A. (2020). Belajar dari Rumah: Potret Ketimpangan Pembelajaran pada Masa Pandemi COVID-19. Smeru Institute, (1), 18

Atiqoh, L. N. (2020). Respon orang tua terhadap pembelajaran daring pada masa pandemi Covid-19. Thufuli: Jurnal Ilmiah Pendidikan Islam Anak. Usia Dini, 2(1), 45-52.

BPS (2019) Potret Pendidikan Indonesia Statistik Pendidikan Indonesia 2019, Tim Penyusun, Badan Pusat Statistik, Jakarta - Indonesia.

Daheri, M., Juliana, J., Deriwanto, D., \& Amda, A. D. (2020). Efektifitas whatsapp sebagai media belajar daring. Jurnal Basicedu, 4(4), 775-783.

Dewi, E. A. (2020). Upaya Orang Tua Buruh Pabrik dalam Membimbing Belajar Anak di Rumah saat Masa Pandemi COVID-19. EduPsyCouns: Journal of Education, Psychology and Counseling, 2(2), 1-13.

Firmansyah, M. I. (2019). PENDIDIKAN AGAMA ISLAM: PENGERTIAN, TUJUAN, DASAR, DAN FUNGSI. taklim, 596.

Firmansyah, M. I., Tantowi, Y. A., \& Fawziah, G. R. MODEL TEAMS GAMES TOURNAMENT: Suatu Analisis Hasil Implementasi dalam Pembelajaran Pendidikan Agama Islam. TARB $A W Y$ : Indonesian Journal of Islamic Education, 6(2), 104-113.

Hamdani, A. R., \& Priatna, A. (2020). Efektifitas implementasi pembelajaran daring (full online) dimasa pandemi Covid-19 pada jenjang Sekolah Dasar di Kabupaten Subang. Didaktik: Jurnal Ilmiah PGSD STKIP Subang, 6(1), 1-9.

Handayani, L. (2020). Keuntungan , Kendala dan Solusi Pembelajaran Online Selama Pandemi Covid-19: Studi Ekploratif di SMPN 3 Bae Kudus. Journal Industrial Engineering \& Management Research (JIEMAR), 1 (Juli),1523. Retrieved from https://www.jiemar.org/index.php /jiemar/article/view/36/24

Kementerian Kesehatan. (2020). Vaksin Covid-19 Belum Ditemukan, Pemerintah Siapkan Skenario New Normal. Kementerian Kesehatan Republik Indonesia.

Lutfiah, S. Z. (2020). Persepsi Orang Tua Mengenai Pembelajaran Online di Rumah Selama Pandemi Covid19. Dealektike, 2(2), 69-73.

Nahdi, D. S., \& Jatisunda, M. G. (2020). Analisis literasi digital calon guru SD dalam pembelajaran berbasis virtual classroom di masa pandemi covid19. Jurnal Cakrawala Pendas, 6(2), 116-123.

Pietro, G., Biagi, F., Costa, P., Karpiński, Z., \& Mazza, J. (2020). The likely impact of COVID-19 on education: Reflections based on the existing literature and recent international datasets (Vol. 30275). Publications Office of the European Union.

Purwanto, A., Pramono, R., Asbari, M., Hyun, C. C., Wijayanti, L. M., \& Putri, R. S. (2020). Studi eksploratif dampak pandemi COVID-19 terhadap proses pembelajaran online di sekolah dasar. EduPsyCouns: Journal of Education, Psychology and Counseling, 2(1), 1-12.

Putria, H., Maula, L. H., \& Uswatun, D. A. (2020). Analisis proses 
pembelajaran dalam jaringan (daring) masa pandemi covid-19 pada guru sekolah dasar. Jurnal Basicedu, 4(4), 861-870.

Rokhani, C. T. S. (2020). Pengaruh Work From Home (WFH) Terhadap Kinerja Guru SD Negeri Dengkek 01 Pati Selama Masa Pandemi Covid-19. EduPsyCouns: Journal of Education, Psychology and Counseling, 2(1), 424-437.

Salehudin, M. (2020). SISWA SD MENGGUNAKAN

SMARTPHONE DALAM

PEMBELAJARAN

ONLINE. IBTID $A^{\prime}, 1$ (2), 229-241.

Sari, D. Y. (2021). POLA ASUH ORANG TUA DALAM MEMBENTUK DISIPLIN ANAK DI MASA PANDEMI. PERNIK: Jurnal Pendidikan Anak Usia Dini, 4(2), 78-92.

Sugiyono,.(2013). Metode Penelitian Pend idikan. Bandung: Alfabeta

Surat Edaran Nomor 4 Tahun 2020 tentang Pelaksanaan Kebijakan Pendidikan dalam Masa Darurat Penyebaran Coronavirus Disease (Covid-19), (2020).

Unicef, \& WHO. (2020). Pesan dan Kegiatan Utama Pencegahan dan Pengendalian Covid-19 di Sekolah. https://www.who.int/docs/defaul t-source/searo/indonesia/covid19 / pesan-dan-kegiatan-

utamapencegahan-danpengendaliancovid-19-di-sekolah--indonesian-march2020.pdf?sfvrsn=5cdfea17_2

WHO. (2020). Coronavirus disease 2019 (Covid-19) Situation Report-101. https://www.who.int/docs/defaul $\mathrm{t}-$

source/coronaviruse/situationrepor ts/20200430-sitrep-101 covid-

19.pdf?sfvrsn $=2 \mathrm{ba} 4 \mathrm{e} 093 \_2$

Zhang, W., \& Zhu, Y. (2017). A new Elearning model based on elastic cloud computing for distance education. Eurasia Journal of Mathematics, Science and Technology Education, 13(12), 8393-8403. 